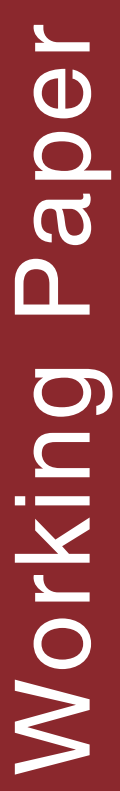

Mohamed Ibrahim, Grace Koech, Jan De Leeuw 


\section{Vision and road map for establishment of a protected area in Laga Badana, Somalia}

Mohamed Ibrahim, Grace Koech, Jan De Leeuw
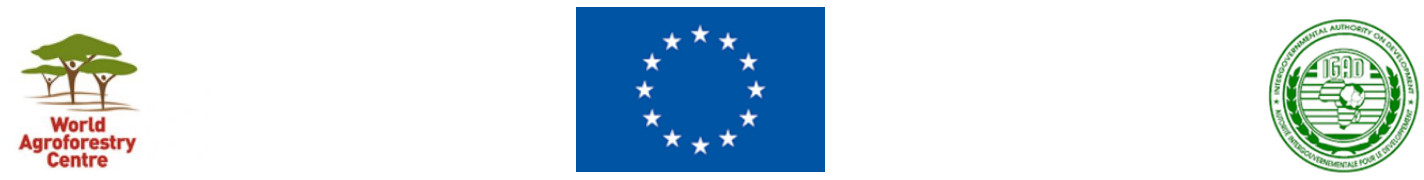


\section{LIMITED CIRCULATION}

World

Agroforestry
Centre

Correct citation: Ibrahim M, Koech G, De Leeuw J, 2016. Vision and road map for establishment of a protected area in Lag Badana, Lower Jubba, Somalia. Working paper no 236. Nairobi, World Agroforestry Centre. DOI: http://dx.doi.org/10.5716/WP16127.PDF

Titles in the Working Paper series aim to disseminate interim results on agroforestry research and practices, and stimulate feedback from the scientific community. Other publication series from the World Agroforestry Centre include: Technical Manuals, Occasional Papers and the Trees for Change Series.

Published by the World Agroforestry Centre

United Nations Avenue

PO Box 30677, GPO 00100

Nairobi, Kenya

Tel: +254 207224000 , via USA +1 6508336645

Email: worldagroforestry@cgiar.org

Website: www.worlagroforestry.org

(C) World Agroforestry Centre 2016

Working Paper No. 236

Photos/illustrations: all photos are appropriately accredited.

The views expressed in this publication are those of the author(s) and not necessarily those of the World Agroforestry Centre.

Articles appearing in this publication may be quoted or reproduced without charge, provided the source is acknowledged.

All images remain the sole property of their source and may not be used for any purpose without written permission from the source. 


\section{TABLE OF CONTENTS}

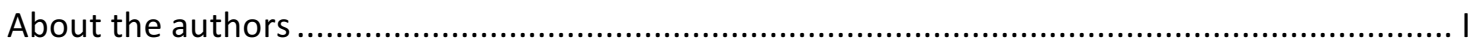

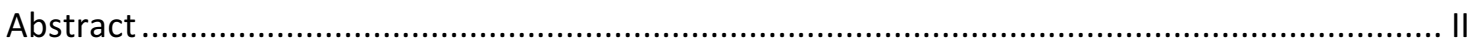

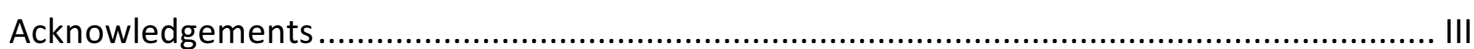

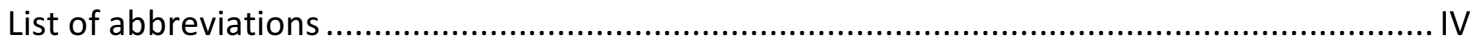

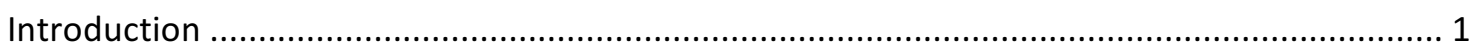



Institutions for protected area management in Somalia ................................................... 4



History of protected areas in the Laga Badana area ..................................................... 10

Description of the area................................................................................................ 11

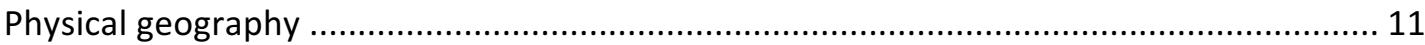

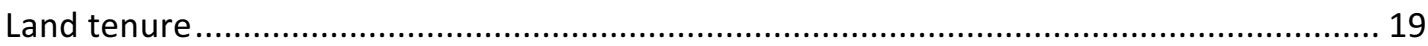

People, land use and livelihoods.......................................................................... 24

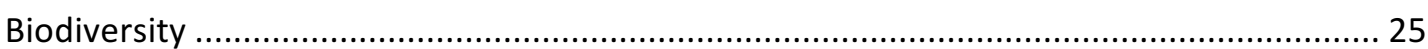

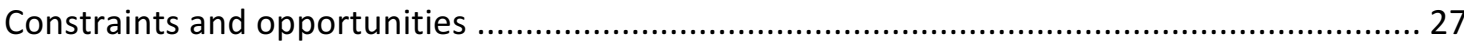

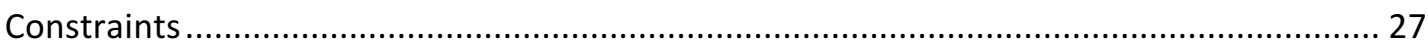

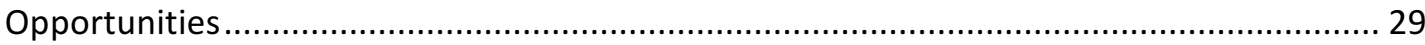

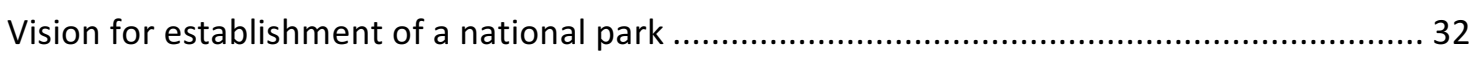

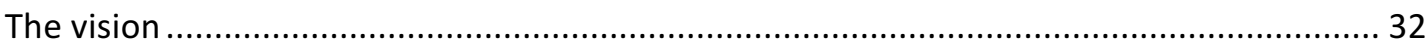

Road map for establishment of a protected area ......................................................... 32

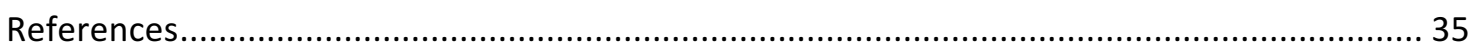

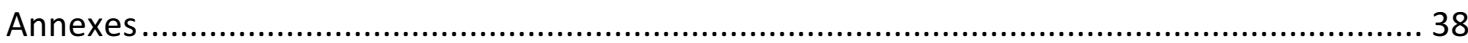

\section{LIST OF TABLES}

Table A1: Evaluation of Fauna in Laga Badana protected area ........................................38

Table A2: Evaluation of Flora in the proposed protected area .........................................40

\section{LIST OF FIGURES}

Figure 1: Location of the Laga Badana area and the game reserves that existed in the 1960s. 11

Figure 2: Average annual rainfall and distribution of tsetse in the Lag Badana area................12

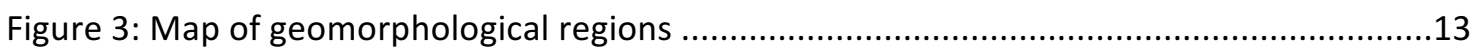

Figure 4: Hydrological zones in the proposed protected area ........................................15

Figure 5: Vegetation types and distribution in the proposed Laga Badana protected area. .....17 


\section{ABOUT THE AUTHORS}

Mohamed Ibrahim is an independent consultant managing Savana Consultancy and Research Services Ltd. Email: mohahibrahim@gmail.com

Grace Koech is a research assistant working for the Biodiversity Management Programme at the World Agroforestry Centre. Email: gracekoech44@gmail.com; g.koech@cgiar.org

Jan de Leeuw is a CIM Integrated Expert Biodiversity and Geo Information Science, Faculty of Ecology and Soil Science, Baku State University. Email: jan45leeuw@gmail.com. 


\section{ABSTRACT}

This paper presents a vision and road map for establishment of a protected area in the Laga Badana area in southern Somalia. The biodiversity of this area has been protected in two conservation areas that were established during the early post-colonial period. It was deemed necessary to strengthen the conservation provided by these protected areas, which were never gazetted and did not allow for engagement of local communities. A UNDP-FAO project implemented in the mid-1970s supported the Government of Somalia with advice to strengthen the conservation of the biodiversity of the area through establishment of a national park. There were also proposals to engage local communities and allow controlled utilization of the resources within the proposed national park. However, for various reasons, including two decades of civil war, the advice to establish a revised conservation area and strengthened park and biodiversity management never materialized. Today, the area is a stronghold of the Al Shabaab, a terrorist group, and highly insecure. This has resulted in degradation of biodiversity with several iconic wildlife species such as the elephant, rhino and hirola having gone extinct, and local communities no longer benefit from the opportunities for socioeconomic development that the conservation areas offered before. This publication offers a vision and a road map to restore conservation of the area's biodiversity and create opportunities for socioeconomic development through the establishment of an ensemble of state-controlled and community-based protected areas.

Keywords: Biodiversity conservation, protected areas, community engagement, road map 


\section{ACKNOWLEDGEMENTS}

This working paper is a product of the Biodiversity Management Programme (BMP) which aims to support the conservation of biodiversity in the cross border area between Kenya and Somalia. It is managed by the World Agroforestry Centre (ICRAF) and funded by the European Union (EU) through IGAD.

The authors would like to express their sincere gratitude to EU through IGAD for funding the activity. Additionally, we would like to acknowledge the contributions of the Ministry of Forest, Range and Livestock of the Federal Government of Somalia, the Ministry of Environment, Mineral and Natural Resources of Jubaland state and local leaders in the project area.

We are also grateful to the local community in Laga Badana area for availing themselves to be interviewed. The critical reviews received from James Acworth (IGAD-TA), Josephat Nyongesa (ICRAF) and Maimbo Malesu (ICRAF) contributed immensely to the quality of the working paper.

Finally, we would like to acknowledge the administrative support from ICRAF in organizing the workshop in Mogadishu and managing other logistics, and the Communications Unit for editing the document. 


\section{LIST OF ABBREVIATIONS}

AfDB African Development Bank

AMISOM African Union Mission in Somalia

BMP Biodiversity Management Programme

CBD Convention on Biological Diversity

EU European Union

FAO Food and Agriculture Organization

GDP Gross Domestic Product

GoS Government of Somalia

ICRAF World Agroforestry Centre

IGAD Intergovernmental Authority on Development

IUCN International Union for Conservation of Nature

SFG Somali Federal Government

UNDP United Nations Development Programme

UNESCO United Nations Educational, Scientific and Cultural Organization 


\section{INTRODUCTION}

The Biodiversity Management Programme (BMP) in the Horn of Africa is an IGAD initiative funded by the European Union (EU). The initiative aims to contribute to poverty reduction by improving the social and economic wellbeing of the populations in the IGAD region, through a more effective regional integration in the environmental sector. Its purpose is the conservation and sustainable management of the ecosystems in the IGAD region, in order to contribute to lasting ecosystem goods and services.

The World Agroforestry Centre is one of the implementing partners and is managing the Tana-Kipini-Laga Badana Bush Bushle Land and Seascape - one of the three projects financed through IGAD. The ICRAF-led activities commenced in late 2013 and will go on until early 2018. It is being implemented in the cross-border land and seascapes of north-eastern Kenya and southern Somalia, an area extending from Tana River, Kenya in the south to the Laga Badana area of Somalia in the north.

BMP involves several complementary project activities. Project activity 4 aims to support the management of conservation areas. In Kenya, where several statemanaged protected areas exist, the BMP project will support the establishment of a community-based conservation area.

In Somalia, there have been attempts to establish a national park in the Laga Badana area to no avail. The country has however, not given up and the project will support stakeholders in the development of a vision and road map for the establishment of a protected area in the Laga Badana area.

This publication describes the vision and road map for establishment of a protected area in the Laga Badana area. The document is the result of consultations with key stakeholders and a stakeholder workshop held in Mogadishu, Somalia on 16-17 November 2015. 


\section{METHODOLOGY}

Establishing a conservation area is a lengthy process that requires the involvement of a large number of stakeholders. The development of a conservation area will change the use of the land and its resources, and thus affect the interests of people who have been using this resource or have an interest in doing so. When developing plans for a protected area, it is important to engage broadly with all possible stakeholders ${ }^{1}$, to ensure that their voices are heard and their interests considered in the development of the plans. Thus, a stakeholder participatory inclusive consultation process was used.

A - Review of existing knowledge and stakeholders. First, existing knowledge on the Laga Badana area was reviewed. It covered reports published in the mid-1970s by Abel (1976) and Abel and Killeh (1976), which were written in the context of a UNDP FAO project that supported the government of Somalia in developing plans for establishment of a national park in the Laga Badana area, country briefs published by the African Development Bank (2013 and 2015) and reports on the biodiversity assessment in Laga Badana area (Gedow 2017). The literature search was complemented with information obtained from key informants and stakeholders from the area.

B - First stakeholder consultation. After this, field visits were conducted on 15-20 April 2015 to Kismayo. It brought together five community leaders from the areas where the park will be established. They comprised four elders and the commissioner of Kamboni. The community leaders were from BuloHaji, Badhadhe area, Yemen or Stambul village, while the commissioner and his colleague were from Kamboni. In addition to the community leaders, those present during the meeting included a colonel from the Somali National Police and two members of parliament of Jubaland.

C - Interim report. Following the review and consultation with stakeholders an interim report was produced.

D - Drafting the vision and road map. Interviews were conducted with various stakeholders between August and October 2015, to document their perspectives on

\footnotetext{
${ }^{1}$ Stakeholder definition: any individual, group or organization who may affect or be affected by the development of the conservation area.
} 
what they thought was key in establishing a vision and plan for a conservation area in the Laga Badana area. During these consultations a number of issues were discussed. They covered:

- The role of local communities, the administration of Jubaland and the Somali Federal Government in establishing and managing a conservation area;

- The type of conservation area and its geographical demarcation;

- The likely impacts of a conservation area on the social and economic wellbeing of the population in the Laga Badana area;

- What should to be implemented in this area;

- Who would participate in the development of a conservation area.

E - Second stakeholder consultation. A two-day consultation workshop was held in Mogadishu on 16-17 of November 2015 to further sensitize the stakeholders in Somalia on the BMP program and seek their endorsement of the vision and road map for the establishment of a conservation area in the Laga Badana area. Elders from the Laga Badana area, the Somalia Federal Government, Jubaland administration, academic institutions and local NGOs working on environmental conservation were represented in this workshop. Following this, the proceedings were published. 


\section{INSTITUTIONS FOR PROTECTED AREA MANAGEMENT IN SOMALIA}

The history of protected area management in Somalia dates back to the colonial times when the first game reserves were established under Italian rule. The UNDP FAO project executed in the 1970s envisaged establishment of a national park in the Laga Badana area. The policies and regulations relevant to the establishment and management of protected areas especially, the international agreements to which Somalia is a signatory were reviewed. The exercise was based on the summary on protected areas of Somalia provided in the Afrotropical volume of Protected Areas of the World (1991) published by IUCN.

\section{Policy and Legislation}

National policy and legislation

Law on fauna and forest conservation: The establishment and management of conservation areas is regulated by the Law on Fauna (Hunting) and Forest Conservation of 25 January 1969 (GoS, 1969). The law has 77 articles covering the conservation of fauna and forests in the country. It also indicated the borders of different protected areas in the country including Bush Bush Game Reserve (Lower Jubba area), Geedkabehleh Game Reserve (Hargeisa Area), Mogadishu Game Reserve (this starts from Mogadishu running along the coast to Adale), Borama District controlled area, the Bush Bush controlled area from Bardera to El Wak, Juba-Lef controlled area (all areas situated on the left side of the Juba River). The law on fauna also has clauses pertaining to the conservation of animals and listed the wildlife species that cannot be hunted throughout the Republic of Somalia.

Policy implementing institutions and the Mogadishu manifesto: In 1971 the National Parks Agency was created as a self-governing body reporting to the Office of the President, with a mandate to implement the law on fauna and forest conservation. A few years later, the mandate of the National Parks Agency was transferred to the Wildlife Department of the National Range Agency which was placed under the Ministry of Livestock, Forestry and Range. In 1989 the President of Somalia issued the Mogadishu Manifesto on the Conservation of Wildlife (GoS, 1989), which specified the institutions responsible for wildlife conservation, namely the National Range Agency 
under the Minster of Livestock, Forestry and Range; the Minister of Foreign Affairs to represent the conservation of the country's wildlife among foreign governments and international organizations, and the Minister of Information to raise public awareness on the importance of the country's wildlife. At present, the Department of Forestry and Range under the Ministry of Livestock, Forestry and Range is responsible for the conservation of wildlife of the country.

Conservation area categories and national parks: The law on Fauna and Forest Conservation covers five categories of conservation areas: game reserves, partial game reserves, controlled areas, forest reserves and grazing reserves. In addition, the Mogadishu Manifesto called for "action to develop national parks and to complete those already in progress such as Bush Bush (i.e., the national park in the Laga Badana area). Proposing the development of national parks gives the impression that there is a legal basis for the establishment of national parks, an impression that was strengthened in 2012 through a call to establish national parks by the President of the Federal Republic of Somalia. However, whereas the law on fauna and forest conservation provides a legal basis for establishment of five categories of conservation areas, it does not offer provisions for the establishment and management of national parks.

Financial support: The financial support to enforce the Law on Fauna and Forest Conservation has remained weak and at times absent. As a consequence, the various protected areas recognized by the Government of Somalia have not received support and resources needed by the institutions, including local park management organizations that could manage the conservation areas. Thus conservation of fauna and protected areas exist only on paper.

State-controlled conservation: The Somali Federal Government is the key player in implementation of the law on fauna and forest conservation. This reflects best practice commonly used until the end of the $20^{\text {th }}$ century which mandated national government agencies to develop and manage conservation areas. The former Government of Somalia, with support from FAO-UNDP, proposed the establishment of a statecontrolled protected area (a national park) in Laga Badana area (Abel 1976). The review of the history of conservation in Laga Badana area indicates that this plan never 
materialized for a variety of reasons, including the outbreak of war between Somalia and Ethiopia in the 1970s. However, this also points to institutional weaknesses; within a period of 15 years of stable government, following completion of the major reports delivered by the FAO-UNDP project (Abel 1976, Abel and Killeh 1976) no progress has been made to revise the law to include legal provisions for the establishment of national parks and to allocate government funds to support state-controlled protected areas. This example from Somalia is not an isolated case. There are many examples from other developing countries where the establishment of state controlled conservation areas has proven to be ineffective, particularly in landscapes where people reside and make use of biodiversity hotpots ${ }^{2}$. Therefore, to develop and manage conservation areas in developing countries such as Somalia, other options could be proposed including participatory community-based conservation.

\section{Participatory community-based conservation: Community-based biodiversity} conservation approaches are considered more appropriate in situations where central government has more urgent issues to handle, such as feed the people and provide health to its population. The development of community-based conservation fits in a broader movement of developing participatory natural resource management, which gained momentum in the late 1980s. A country like Kenya has provision for participatory management of water resources (implemented by Rural Water User Associations established under the Water Act of 2002), participatory forest resources management (Community Forest Associations made possible by the Forest Act of 2005) and for participatory wildlife conservation and protected area management (through establishment of Community Wildlife Conservancies made possible by the Wildlife Conservation and Management Act of 2013). Similar policy reform to develop legal provisions to allow participatory natural resource management has taken or is taking place in other East African countries like Tanzania and Uganda. Efforts to reform legislation in natural resource management were never initiated in Somalia as the country entered two decades of civil war when the neighbouring countries first begun to implement this approach in the 1990s. Because of this, Somalia does not have legal

\footnotetext{
${ }^{2}$ Berkes F. 2004. Rethinking Community-Based Conservation. Conservation Biology 18: 621-630
} 
instruments to support the development of community-based wildlife conservation and protected area management. However, this approach could be the most appropriate one for the development and management of wildlife conservation in Somalia once security is restored.

Devolution: Since the end of the civil war, Somalia has gone through a process of decentralization and devolution of government authority. In 2012, the previous centralized state was transformed into a Federal State to allow for greater autonomy of the various regions of the country. Today, Somalia has five autonomous federal member states, including Somaliland in the north, Puntland in northeast, Galmudug, Southwest and Jubaland in the south-central part of the country. The final number of federal member states will be six (excluding Benadir region) after the formation of Hiiran and Middle Shabelle Regional State. The political decentralization has resulted in a devolved government, with each member state having its own administration. All this has had an effect on the conservation of wildlife and protected area management in several ways.

The devolution process demanded goodwill from politicians and government, thus delaying necessary efforts to re-establish and revise environmental policies and institutions. This is particularly so for Jubaland. Second, devolution has created a situation where it is unclear whether mandates established under the former centralized government lie with the Federal Government or the administration of the federal member states. This lack of clarity results in flaring up of rivalry for mandate between the two levels of government whenever there is discussion on natural resource management or the establishment of protected areas. For example, during the workshops, a lot of time was devoted to discussions on the authority of the administration of the Jubaland Federal Member State and its desire to cooperate with the central government. However, for Laga Badana conservation area which has been discussed for the last two years of the project, the rivalry has been minimized as there were very constructive discussions between the Jubaland Administration and the Federal Government. 


\section{Multilateral and international agreements}

Global international agreements: The Federal Government of Somalia is a signatory to various international agreements relevant to nature and biodiversity conservation. It ratified the Convention on Biological Diversity on 11 September 2009 and the Ministry of Fisheries and Marine Resources recently published a report on the country's commitment to the CBD (MoFMR 2014). At present, there are no clear mandates for the ministries operating on environmental and natural resources and this complicates the issue of which ministry holds the mandate to represent the Somali Government to the CBD. So far, the country has not ratified other relevant agreements such as the Ramsar Convention, the UNESCO World Heritage Convention and the Bonn Convention on Migratory Species.

Regional agreements: In addition to this, Somalia has signed several regional agreements such as the Regional Convention for the Conservation of the Red Sea and the Gulf of Aden Environment also known as the Jeddah Convention, Protocol on Protected Areas and Wild Fauna and Flora in the Eastern African Region and the African Convention on the Conservation of Nature and Natural Resources. At the time the Mogadishu Manifesto specified that the Minister of Foreign Affairs was responsible for these agreements. However, the commitment of Somalia towards honouring the agreements has been weak and unreliable since the collapse of the former regime in 1991 (AfDB 2013).

Cross-border cooperation: Increasingly there is an interest to develop cross-border cooperation in biodiversity conservation. The reason for this is that biodiversity extends across the borders of individual states and there are opportunities to connect conservation efforts across borders to ensure that conservation efforts on one side of the border are connected to conservation efforts on the other side. Cross-border cooperation in biodiversity conservation and protected area management is also foreseen in the BMP project; one of the project activities aims at developing a vision and road map towards the establishment of a cross-border protected area. There are several potential advantages of such a contiguous protected area, including the possibility of wildlife species still present on one side of the border to recolonize the other side of the border, the increased viability of larger species populations when 
ensuring proper connectivity of meta populations that might otherwise be affected by genetic isolation and the exchange of experiences among stakeholders on both sides of the border. At present the Federal Republic of Somalia does not have any cross-border cooperation in biodiversity conservation and protected area management with any of its neighbours. The IGAD-BMP project offers Somali society to develop its first steps towards establishing cross border cooperation in biodiversity conservation. For this purpose, there were several cross border meetings which were organized in different parts of Kenya. For each of these meetings there were representatives from Somalia who were in a way or another interested/involved in biodiversity conservation. The main obstacles which limit these cross border efforts between Somalia and Kenya include the security and the immigration system. The latter particularly limits the movement of the Somali citizens as they are required visas for the entry which is mostly denied by the Kenya immigration authorities. 


\section{HISTORY OF PROTECTED AREAS IN THE LAGA BADANA AREA}

The Italian colonial rulers established a game reserve in the Laga Badana area in the early 1950s when they established the Bubashi Absolute Reserve under Ordinaza no. 26 (Funaioli \& Simonneta 1966). This absolute reserve was to include a National Fauna Park of Laga Badana. After Somalia gained independence, the government promulgated a new conservation law referred to as, "The law no. 15 of January 25, 1969 on Fauna (Hunting) and Forest Conservation". This law changed the conservation status of the area to that of a game reserve, the Bush Bush Game Reserve (FAOLEX 1969, Abel and Killeh 1976a). In 1971, the National Parks Agency (NPA) was created as a self-governing body reporting to the Office of the President. A few years later this NPA was transformed into the Wildlife Department, and placed under the Ministry of Livestock, Forestry and Range. At the time, it was the intention of the Somali government to establish the park in this extreme tip of southern Somalia. It sought assistance from UNDP and FAO to provide advice on the establishment of a national park. These two organizations supported the government's ambition to establish the park with several studies conducted by Abel and Killeh from 1975 to 1977. The project produced a series of policy and management reports. However, the establishment of the Laga Badana National Park has never materialized due to the political instability in Somalia. Hence, legally speaking, the Bush Bush Game Reserve that was established in 1969 remains the only protected area in the Laga Badana area. However, its exact boundaries have never been established and gazetted and this remains one of the main tasks of the Somali Government and the Regional States. 


\section{DESCRIPTION OF THE AREA}

The vegetation in Laga Badana area is deciduous bushland and thicket, with coastal dune grasslands having scattered bushes, herbs and shrubs (Davis et al. 1994, White 1983). The bushy vegetation at the coast has been sandblasted by winds to form a specialized community of low, dense thickets (Kingdom, 1997). The main species in the area include Aerva javanica, Indigofera sparteola, Jatropha pelargoniifolia (glandulosa) and Farsetia longisiliqua (Davis et al. 1994).

\section{Physical geography}

\section{Location}

The Laga Badana area is located in lower Jubba in the southern tip of Somalia (Figure 1). The area is situated between $1^{0} 09^{\prime} 34.84^{\prime \prime} \mathrm{S} ; 41^{0} 13^{\prime} 12.12^{\prime \prime} \mathrm{E}, 51 \mathrm{~m}$ in the North West; $1^{0} 07^{\prime} 22.52^{\prime \prime} S 41^{\circ} 55^{\prime} 46.58^{\prime \prime} E, 5 \mathrm{~m}$ in the North East $1^{0} 38^{\prime} 43.72^{\prime \prime} S ; 41^{0} 34^{\prime} 00.43^{\prime \prime} \mathrm{E}$ in the South.

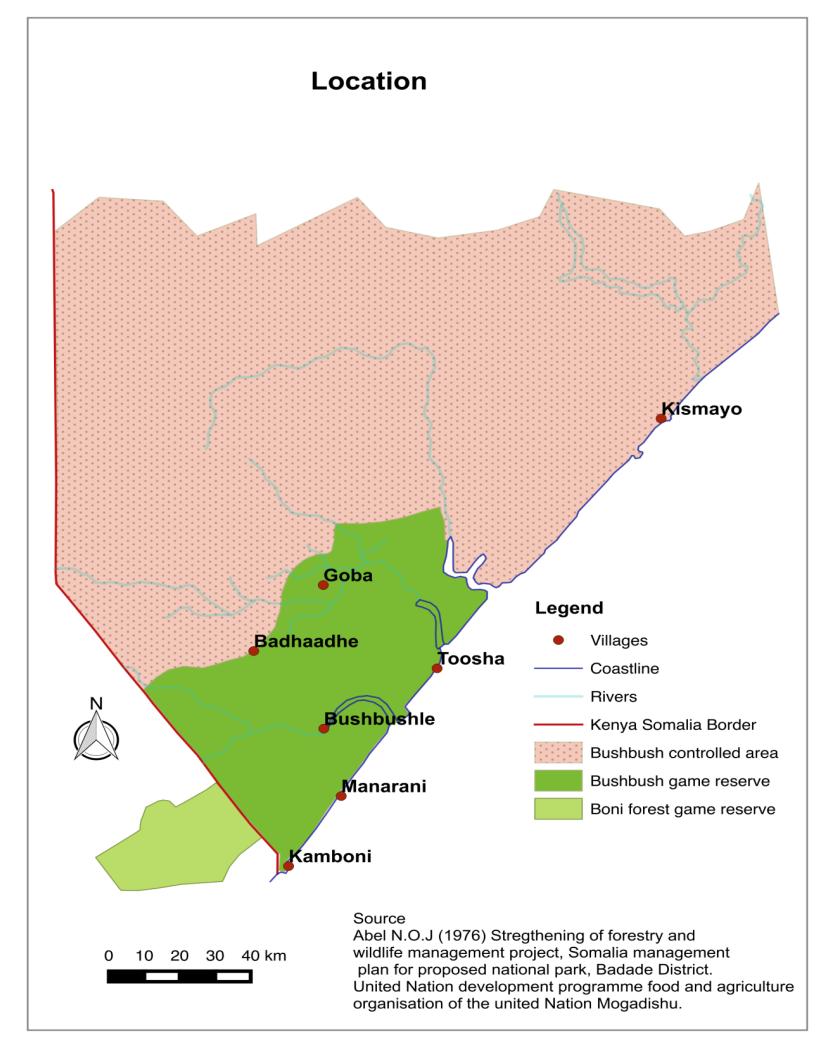

Source Abel, 1976

Figure 1: Location of the Laga Badana area and the game reserves that existed in the 1960s. 


\section{Climate}

The climate of the Laga Badana area is semi-arid with bi-annual unreliable rainfall. The area experiences four distinct seasons as other parts of the South Somalia. 1) Jilal is the dry season between December and March, 2) Gu' is the rainy season from April to June, 3) Haga is the dry season from June to late September while 4) Deyr is a short rain season from October to mid-December. It is documented that the annual average rainfall of the area range varies both in quantity and distribution with a range of 400 $600 \mathrm{~mm}$. The Laga Badana area is classified as semi-arid with summer precipitation and temperatures of $20-30^{\circ} \mathrm{C}$. The areas along the coast of the park are climatically arid with summer precipitation and temperatures higher than $30^{\circ} \mathrm{C}^{\circ} \mathrm{C}$ (Abel 1976, Abel and Kille 1976).

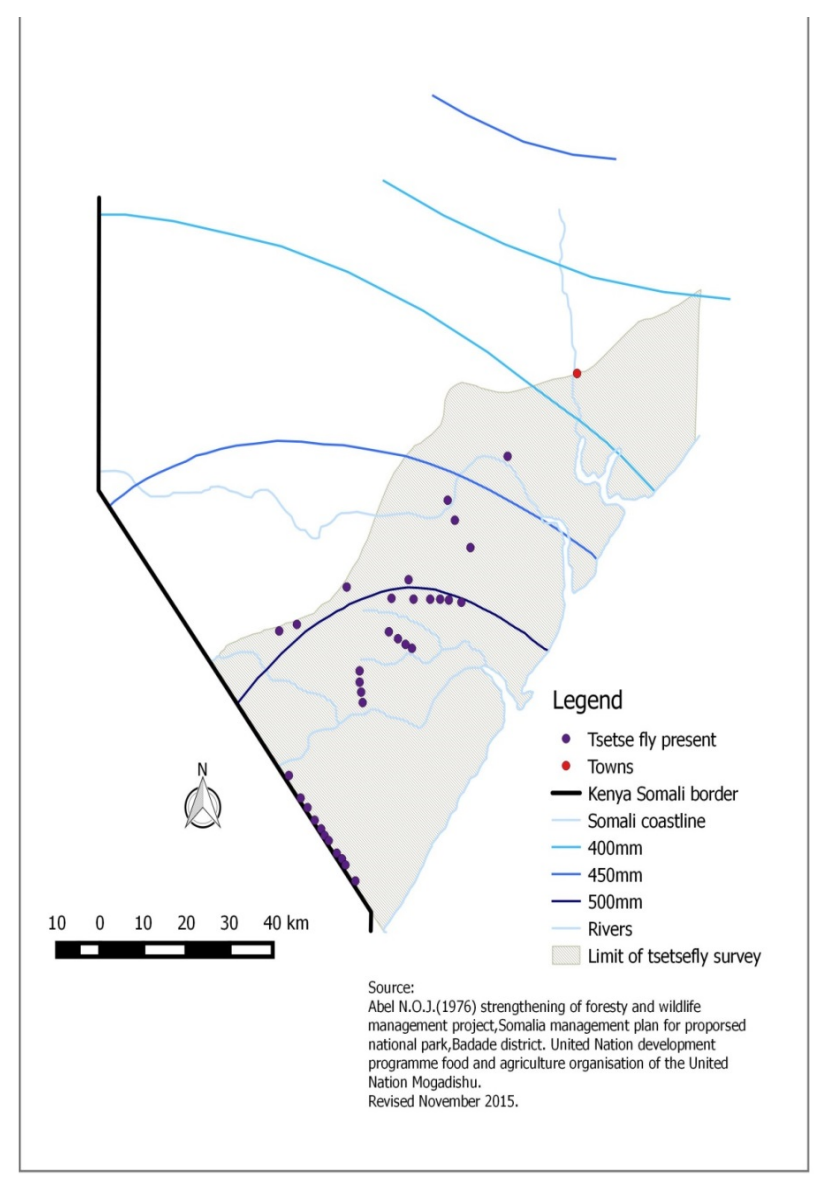

Source Abel, 1976

Figure 2: Average annual rainfall and distribution of tsetse in the Laga Badana area. 


\section{Geomorphology and Soils}

The Laga Badana area consists of an area with flat topography with three main landforms (Figure 3) that were described by Abel (1976).

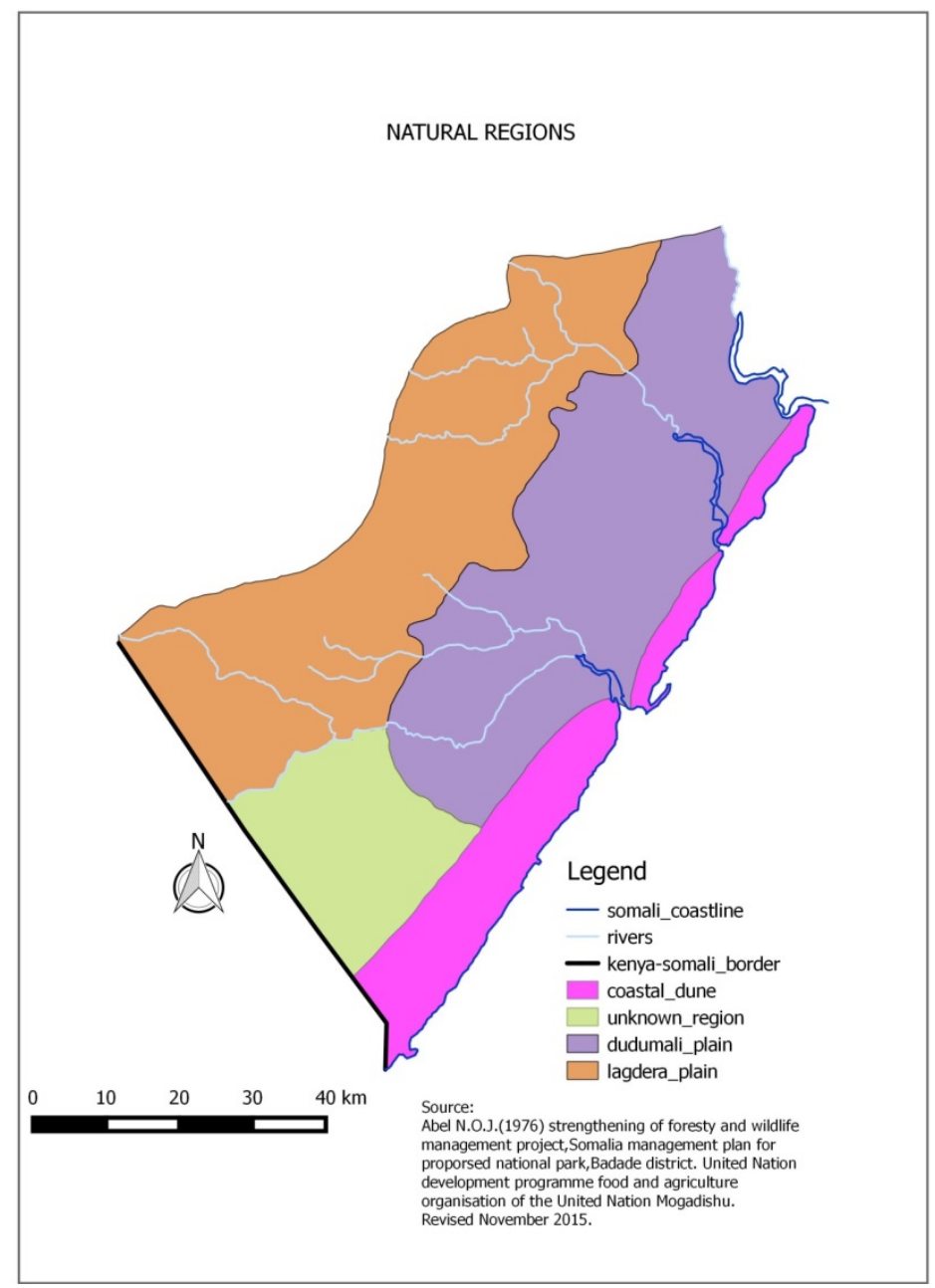

Source Abel, 1976

Figure 3: Map of geomorphological regions.

Dudumali Plain Region is a landform type classified as 'mantled plain limestone' meaning a plain having a mantle of residual materials derived by weather from underlying bedrock. The topography is level and the soil is fine textured, dark red to dusky red developed in a fine mantle of weathered coral lime stone. These areas are not used for cultivation but are favourable for grazing. The surface is smooth and often has a material and hard and firm where the smear is not present. The sub-soil materials are usually red clay with weathered limestone material about $50 \mathrm{~cm}$ below the surface (Abel 1976). 
The Lag Dera Plain Region is the area north of Lag Bush Bush and Lag Gareb, which is a flood plain complex of meander scrolls, ox-bow lakes and levees. It is composed of coarse textured and fine textured soils with colours ranging from brown, reddish-brown to grey or grey-brown. The parent material is from the flood deposits from the Lac Dera, Lac Gera and Lac Bisik from Wajir and El Wak in Kenya. It has a firm surface but often smear sandy and fine gravel-like materials. The texture of the surface mainly comprises fine sandy loam to fine sandy clay. These soils are saline with a high content of sodium, which is known to be hazardous to cultivation. Although, these soils are not good for crop production, the area provides pastures for large animals and would be good if it would be considered as a rangeland or incorporated into a natural reserve (Panayotou 1994).

Coastal Dune Region consists of coastal hills and dunes. Sand from this region has been blown to the hinterland and deposits of white eolian sand are prevalent between Lag Bush Bush, Lag Garabey and the coastal dune region. Livestock grazing and off-road driving denude the dunes, exposing the sand to wind erosion into the park could affect the vegetation and wildlife habitats (Abel 1976ab).

\section{Hydrology}

An ample supply of water is important for the people, their livestock and also for the wildlife living in the area. The Laga Badana area is characterized by perennial and ephemeral rivers, natural and artificial ponds and pools, and boreholes and shallow wells that rely on the area's groundwater. The surveys carried out by Abel in the 1970s indicate that these sources provided water to human, livestock and wildlife throughout the year. The permanent water sources were particularly important during the dry season, when surface water becomes scarce. Hence, in the past the Laga Badana area, where the protected area is proposed, enjoyed a good supply of surface water. However, surveys with key stakeholders suggest that the supply of surface water has deteriorated since the 1970s. Workshop participants noted that many of the water holes that were permanent in the past, nowadays dry up before the end of the dry season. 
Within the Laga Badana area, the natural and semi-permanent water holes are classified by the inhabitants as follows: Shamku, Gisile, Bush Bushle Dera, BonWirde Isu, Malka Robi and Malka Jira (Interim Report 2015, Workshop Report 2016).

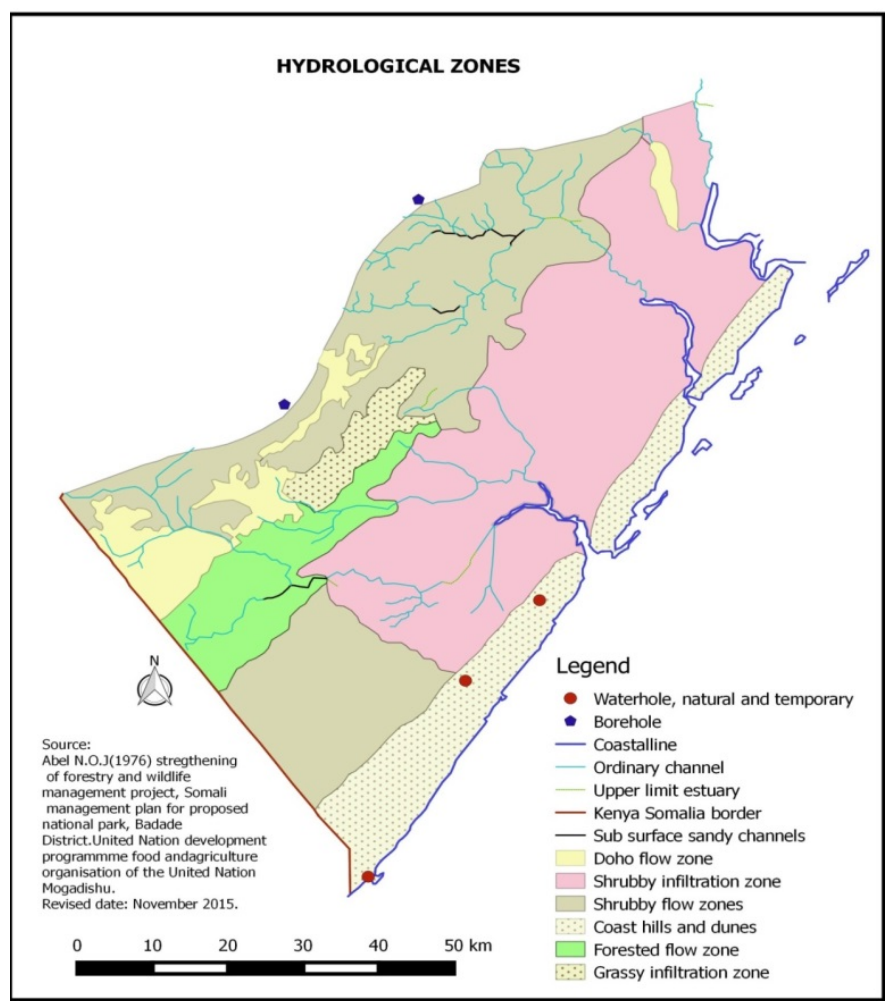

Source Abel, 1976

Figure 4: Hydrological zones in the proposed protected area.

\section{Tsetse}

The report written by Abel (1976) indicated that in the past the park was highly infested with tsetse fly making it unsuitable for livestock rearing. This posed a problem to pastoralists and farmers wishing to graze livestock and cultivate crops. At the same time, the presence of tsetse has been key to the conservation value of the area for a number of reasons. Wild animals have become resistant to trypanosomes as they evolved together with tsetse. There is limited competition between wildlife and livestock or crop-based farming because the presence of tsetse keeps the livestock and farmers out of the area, at least during the rainy season. Hence, the presence of tsetse has contributed to the rich biodiversity of mammal species of the area. Tsetse flies 
thrive in woodlands and bushlands, where the canopy of trees and bushes create the shaded moist soil conditions that provide the ideal habitat for its reproduction. Clearing bushes is one of the common methods used to eradicate tsetse flies. There are oral reports (personal contacts) that collection of wood for charcoal production has opened up the woodlands and bushlands of the Laga Badana area. It is not clear what effect this has had on the presence of tsetse flies. Few people venture into the area at present, due to insecurity as it has become a hideout for the Al Shabaab militants.

\section{Vegetation}

The Laga Badana area supports various vegetation types (Figure 5). While ecological classification is a broad categorization based on the climate of the area, physiognomy narrows down to growth forms of the plants, and relative amounts of woody and nonwoody species. Abel (1976) described and mapped (Figure 5) the following physiognomic vegetation types within the area that they proposed for the national park: The authors have summarized the region vegetation as below;

Bushland: Land supporting single or layered canopy of trees and shrubs not exceeding $10 \mathrm{~m}$. The ground cover is poor and epiphytes may occur. The extreme form of bush land is bushland thickets where woody plants can pass with extreme difficulty and has no grazing value. In the Laga Badana protected area, the bushland vegetation is further categorized into:

Bushland B: Bushland B describes the vegetation found on Lag Dera plain region and unclassified area between Lag Garebey and Coastal Dune Region (Pratt et al. 1966). The canopy cover ranges from dense to fairly open canopy. Combretum shrubs are dominant in this region while annual grasses cover area near villages, towns grazing fields and waterholes. Perennial grasses are common in areas where grazing is limited mainly in the Tsetse fly infested areas. Bush land B vegetation has been altered mainly by wild animals, livestock and human activities such as agriculture.

Bushland on red sand over limestone (BCr): Bushland on red sand over limestone bush land vegetation cover the largest part of the park and grows on Chisimaio' soil in the Dudumali plain region. The vegetation density increases towards the Lag bush bush. 
Perennial grasses may be found depending of presence of livestock and density of the shrubs.

Bushland on coastal dunes and hills: Bushland on coastal dunes and hills is found along the coast of the protected area. The vegetation in this region has been altered by shifting cultivation and livestock. Acacia tortilis is the dominant species. The ground is layered with perennial grasses such as Chloris and Dactylocteniumspp. In absence of perennial grasses, the ground is covered by coral reefs and dwarf shrubs of Sterculia spp. (Abel, 1976).

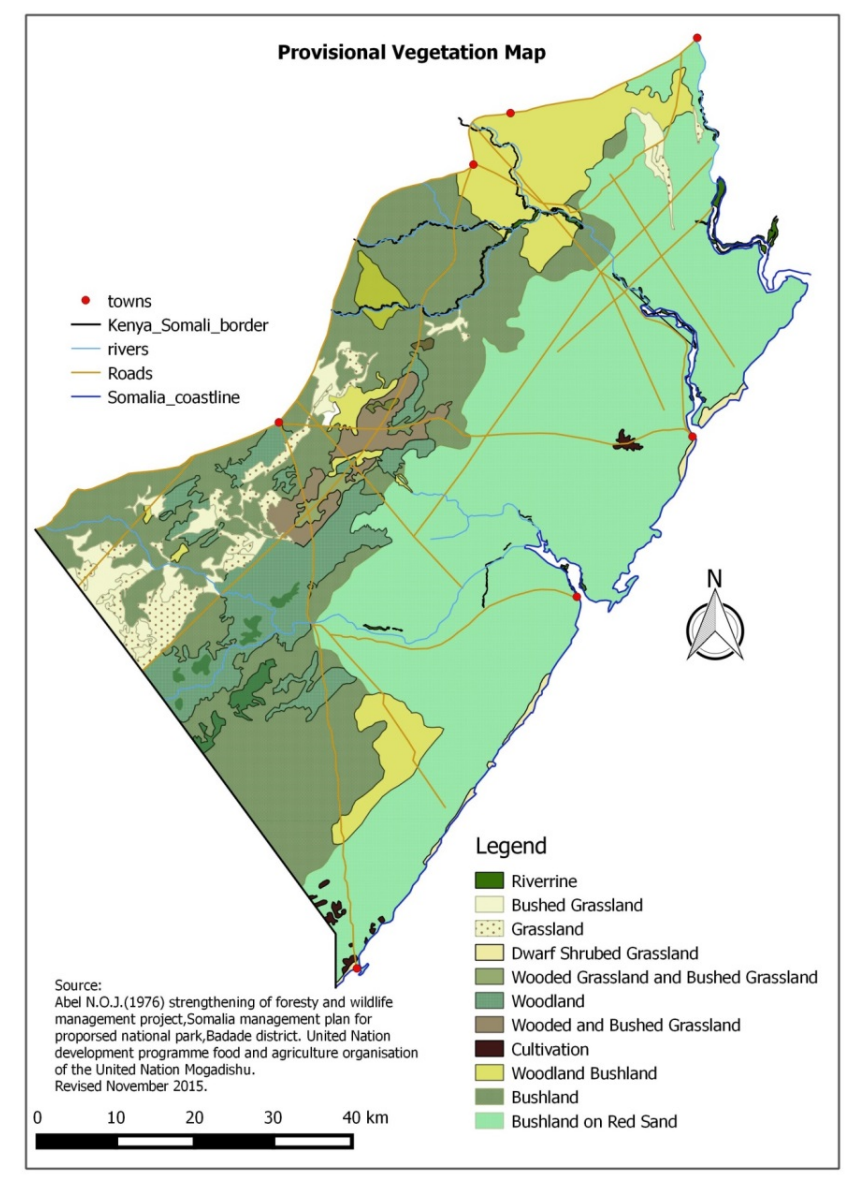

Source Abel, 1975

Figure 5: Vegetation types and distribution in the proposed Laga Badana protected area.

Grassland: Land dominated by grasses, herbs, scattered trees and shrubs with a canopy cover not exceeding two percent. The grassland vegetation is subject to frequent burning. Subtypes of grassland vegetation include sparse grassland and bamboo 
thicket. Grassland vegetation is described as giant when vegetation exceed $300 \mathrm{~cm}$, tall where the vegetation is $150-300 \mathrm{~cm}$, short if under $25 \mathrm{~cm}$ and dwarf when the vegetation is less than $10 \mathrm{~cm}$. Based on the level of being swampy, the grassland vegetation can be described as seasonally flooded or seasonally water-logged. The grassland vegetation is further classified based on dominance by annual grasses and other herbs i.e. annual grassland and herb grassland. Grassland vegetation which does not qualify to classification based on drainage and vegetation dominance is presumed as free draining land dominated by perennial grass.

In the protected area, the grassland vegetation is described as medium height and seasonally waterlogged. Perennial grasses; Setaria and Sphacelata are the dominant grasses in the region. Acacia seyal is the common tree species. In areas where settlement is evident the annual grass density increases while the height decreases (Abel, 1976).

Bush Grassland Vegetation: Bush Grassland is a grassland vegetation with scattered trees and shrubs which is not necessarily equally represented but both are conspicuous with a canopy cover of less than $20 \%$. The vegetation is exposed to periodic burning.

Woodland plus Bushland: This is a mixed vegetation type with trees including Terminalia, Delonix and Adansonia digitata (baobab). The shrub layer is made of Combretum and Acacia. Figure 3 shows a woodland pattern of dark toned trees with in between grey and white, which represents understory vegetation and the whitish calcareous soils. This pattern is characteristic for grazed woodland. Apart from bush land, woodland is similarly prevalent in this area standing to about $18 \mathrm{~m}$ high with either open or continuous canopy but not interlaced. They grow on grey water logged clay soil at times logged for long periods. Most of these vegetation types have been turned into secondary bush through shifting cultivation that is practiced by the hunter-cultivators (Abel 1976).

Wooded and Bushed Grassland: Is the medium height Sporobolus terminalia where grass is perennial and the soil is free draining sand. Past human activity might have led to openness of the vegetation in the area. Wooded Grassland plus Bushed Grass land is 
a composite type that is similar to the wooded and bushed grassland type with which it is contiguous (Abel 1976).

Riparian forest: This is a strip of forests growing along the banks and in the beds of the streams - 'Lagag' (where the name of the protected area originated) with Diospyros, Garcinia and Ficus species of trees. The vegetation around permanent watering places had been altered greatly owing to grazing by cattle, elephants and human activities. The riparian vegetation was described to be in good condition with little soil erosion at the time of the surveys in the 1970s. Google earth imagery reveals a rather closed canopy of the riparian forest, suggesting that these systems are still intact. This observation contradicts the assumption that the often-mentioned export of charcoal would have destroyed all forest in the area of the proposed protected area.

Coastal dune region: The natural regions identified then included coastal dune region consisting of coastal hills and dunes (Figure 5). Though not found within the park, sand had been blown to the hinterland and deposits of white Eolian sand were common between the coastal dune region and Lag Bush Bush, Lag Garabey. Just like other areas of Somalia's coast, a combination of unlimited off-road driving and livestock grazing denude the dunes, exposing the sand to wind erosion. The sand blown into the park could affect the vegetation and wildlife habitats, but its impact could be assessed in future. Moreover, Dudumali Plain Region is a landform type classified by FAO as 'mantled plain limestone' (FAO 1968). The Lag Dera Plain Region is the area north of Lag Bush Bush and Lag Garebey. The area was classified as flood plain meander. The soils are not good for growing crops and the area is home to a large animal population, since they contained good grasslands they would be considered for a rangeland or incorporated into a natural reserve (Abel and Killeh 1976).

\section{Land tenure}

The Somali formal land tenure system was established under the colonial regimes of the British in the north (current Somaliland) and the Italians in the south (South Central). In the Italian-controlled territory of southern Somalia, the first official land tenure policy was launched and some of the decrees signed at that time included the Royal Decree 695 of 8 June 1911 and Governor's decree 815 of 19 January 1912 which 
were collectively established for the Italian colonial state's right of sovereignty over vacant lands (those lands in excess of Somali population present and future needs at the time) and its right to issue agricultural concession out of state domain for Italian citizens or other foreign nationals (Samatar 1993).

During the rule of Siad Barre (1969-1990), a series of agrarian reforms were legalized which were aimed at stimulating growth and development of the agricultural sector in the country. The Somali government passed 22 laws regulating the agricultural sector to increase its crop production. A new land tenure law was adopted by the government and it was declared that all land belonged to the state and would be administered by the government. This law effectively nationalized the communal rangelands and agricultural schemes. They also nullified the customary treaties between pastoralists over rangeland management (Ruth 1993, Bradbury 1997).

Land tenure institutions have a direct effect on the land use in the Laga Badana area. Traditionally, the most common form of land acquisition in Somalia is family inheritance, purchase and local government allocation. The inheritance process is traditionally handled by informal committees that have been formed based on clan representatives after consultations with respected clan and religious leaders. Chiefs from sub-clans distribute the land, with the support of traditional elders, based on the same clan system. Land grabbing and illegal acquisition of land has been observed in Lower Shabelle, Banadir and Lower Juba in the south. Similarly, in most Somali communities, land distribution among community members usually occurs through traditional ownership system by clan leaders, mostly on clan/family basis, with the respect of their application of customary law (Xeer). Depending on the clan system, each community/clan has its traditional system of ruling by elders and chiefs (in Somali: Caaqillo, Suldanno and Ugaasyo) who were selected among the most respected members of their community.

Regarding land conflict management, traditional leaders, village committees, religious figures and business groups are involved in reaching compromises or peaceful resolutions. Early involvement of the elders and other dispute resolution mechanisms can ensure compromise and peaceful resolutions. Apart from the issues related to settlements within the communal areas, scarcity of water, grazing and pasture rights 
are the leading cause of conflicts among Somali communities. Other causative factors include lack of separate and effective land law between pastoralists and crop producers.

At present, in most instances of conflict, the customary traditional systems of conflict resolution are employed. Mediation by traditional elders is the preferred channel of redress for aggrieved parties. The verdicts of the traditional and religious leaders (such as Sultans and Chiefs) are highly accepted and relied upon by disputants more often than not, as compared to their dependence or consultation of law courts, particularly when it comes to resolution of land related conflicts. The procedure of land conflict resolution is an established process starting from the complainant up to Guurti (traditional elders established to intervene). The Guurti comprise elders selected for their knowledge and experience in their community.

The length of land conflict resolution process depends on the magnitude of the complaint; if the case is seen as inconsequential then it can be addressed by immediate family members (husband or parents). However, if it is more complex, chiefs and elders have to intervene. The Guurti is the ultimate body that intervenes if complaints are escalated or appealed.

Even though, every person in the community has the right to access and use land for grazing purposes, for instance, land is pre-dominantly used for livestock grazing and farming. Through the consultation meetings in Kismayo and Mogadishu, elders from communities agreed that the presence of land as a communal asset is important and this is in line with the views of other communities in other parts of the country. The main reason for this assertion is because of lack of a variety in terms of availability of resources. Therefore, land is considered the most important and valuable natural asset according to the participants. The communal ownership of land and land use minimizes conflicts, while maximizing the utility of land for their primary livelihood, which is pastoralism in many areas of Somalia, including the Laga Badana area.

Women, children and other vulnerable groups such as internally displaced people (IDP) and minority groups are the community groups most affected by all forms of land conflicts in many parts of Somalia. This is because these groups have little or no control 
over land ownership, particularly women, who are traditionally considered inferior (or with lesser rights than men) and are not included in the village committees or elders in the community. Where these traditional systems are used, the elders gather at a predetermined location (usually under a tree) where the conflicting parties meet and give their different sides of the matter at hand. Solutions or judgments are also handed down at the same location and in a similar manner, once the elders arrive at a consensus.

Regarding land laws and rights, in Somalia, generally, all members of any community anywhere in the country have the right to own land, which they are free to donate, sell or allocate to their family members as inheritance. They are also allowed to lease or rent it out. Individuals and the community in general secure this right to land ownership either through government certification of land ownership which is commonly used in cities and towns or through the approval and guidance of traditional elders in the area. However, traditional systems remain the primary source of protection of individual and community land rights enforced by the clan elders with the support of religious leaders. Nevertheless, lack of a proper government structure and system in the country, coupled with poor representation at the local level, are the main impediments to the enforcement of these land rights and laws in the communities where they exist. Other reasons includ lack of community participation and awareness, lack of respect for traditional government systems, prioritizing of clan loyalties above community wellbeing, inability to enforce laws due to weak institutions (lack of human and technical resources) and corruption.

The collapse of Somalia's Central Government in 1991 led to the breakdown of the institutional structure of the country resulting in the appropriation of land ownership and water resources by illegal use of force in some parts of the country. The insecurity and chaos that followed the collapse have had an overwhelming negative impact on the social, political and economic development of Somalia. As the security is returning to normal in many parts of the country and the SFG gains more ground in south central Somalia, the settlement of on-going land conflicts is a crucial one for the country. However, the current land conflicts have to take into account three different dynamics 
according to the different administrational periods that the country has passed through:

- A first dynamic between 1969 and 1990: The government appropriated vast chunks of land from individuals and communities through legislation (e.g. Law No. 25) and allocated to cooperatives organizations, private entities including government functionaries for commercial farming. The process was viewed as an illegal act by the affected individuals and communities and created a sense of injustice.

- A second dynamic is rooted in one law of war: many of the conflicts seen today in many parts of Somalia are rooted in longer histories of disputes among neighbouring clans over land and water, mainly for grazing of their animals. Realignment of power among the country's political elite can affect claims to resource rights in the rural peripheries, just as rural struggles for control of strategic resources reshape alliances at the centre. Access to land, as a source of security, status, and revenue, is an emotive issue which politicians at all levels use to secure the support of their relatives and area of origin.

- The last dynamic is the spatial expression of the war and humanitarian crises for more than a generation. Because of extreme hardship, people moved to town and gave up or left unoccupied lands and properties that are nowadays occupied by new migrants.

From the above it is clear that there is no reliable government system in most of Somalia. Currently, the only effective system that could resolve land conflict is the traditional one where clan elders and religious leaders preside over disputes. Therefore, the traditional system can provide support in the establishment of the protected area through community participation since the influence of elders and religious leaders in the community is stronger than that of the formal system controlled by the government of local authorities. 


\section{People, land use and livelihoods}

Hunting gatherers

A group of people composed of hunter-gatherers and honey producers known as Aweer used to reside permanently in the interior part of the proposed protected area. The population was estimated at about 200 and they mainly relied on wild products collected from nature and practised shifting agriculture along streams. The huntergatherers used to live near forests in the areas of Wayore, Hola Wajer and Sadeh Lugod. This group migrated from the area during the civil war, crossing the border into Kenya. Most of them settled in Boni Forest.

\section{Coastal people}

This is a population of 3,000 people living either permanently or temporarily along the Indian Ocean coast in the villages of Yeman, Kudha, Stamboul, Yasini, Tosha Sheya, Kidivani, Navava, Burgabo, Oda, Kamboni and Manarani. The majority are fishermen and traders. They also practise some agriculture on fragile red sand of the coastal dunes, and rear livestock (cattle, sheep and goats).

\section{Pastoralists}

Pastoralism is not common in the protected area due to the presence of tsetse fly infestation. Pastoralists bring their cattle to the protected area during the Jilal season for grazing. During the dry season they use Malka Robi and Malka Ari for watering their animals. These fuel conflicts because availability of water is one of the major constraints facing pastoralists in Somalia. Coastal pastoralists use water points at Shamku, Gisile and coastal wells for watering of their animals. In some parts of the coast, wells are bitter and communities living in the Burgavo area have to source their drinking water from Bush Bushle area.

\section{Settlements and transport}

In Laga Badana area the main means of transport along Kamboni, Burgavo, Kudayo, Stamboul and Kismayo is by boat. Road transport is possible between Kismayo and Badhadhe to the border of Kenya and Somalia though it is limited during rainy seasons due to flooded streams and soil deposits which causes water logging. 
The settlements in and around the proposed protected area include the following:

- In coastal areas, the villages of Kamboni, Oodow, Manarani, Burgabo, Kudha, Tosha and Sheye

- In the north, communities have settled in Anole, BuloHaji, Abaloley and Saidey villages.

- In the south communities have settled in Kulbiyow, Janaan and Gudban

- In the west are Garruur, Hailow, Santaaro, Da'arey, Mandheerkurmo and Waraq/Weylo-ad

- Settlements inside the protected area include Halima Adey, Wadajir, Wardaay Faqir, Gobaa, Gasay Kuuso, Badhaadhe, Dallaayad and Bush Bushle.

Most of the communities living in these areas are farmers, pastoralists, fishermen and small-scale businesspeople.

Within the protected area, communities draw their water from:

1. Quraan Laga, located in BuuloHaji area

2. Malka Jira, located in Kudhaa area in the middle of the protected area

3. Hoolaa-Wajir, located in Buurgaabo area.

\section{Biodiversity}

Terrestrial biodiversity: The south-eastern tip of Somalia is rich in biodiversity. The terrestrial part of the area hosts coastal drylands forests which form the northern tip of the East African Coastal Forest Biodiversity Hotspot, one of the 35 global biodiversity hotspots recognized by Conservation International'. This biodiversity hotspot, which extends from southern Somalia to northern Mozambique, hosts 1750 endemic plant species. Gedow et al (2016) who recently reviewed the floral and vertebrate biodiversity of the area reported 916 plant species of which 32 were endemic. They also reported 524 species of vertebrates with 293 birds, 100 mammals, and 93 reptiles and amphibian. Several of the large herbivores are now extinct (e.g. Elephant, White Rhinoceros, Giraffe, Buffalo, Hirola) as a result of unregulated hunting and poaching. 
This area hosted part of the world's population of the Hirola or Hunter's Hartebeest (Beatragus hunteri), an endemic and globally endangered antelope species, which is now extinct in Somalia. Several mammal carnivore species such as the lion, leopard and the African hunting dog as well as several endangered vulture species namely the Hooded Vulture (Necrosyrtes monachus CR), White-backed Vulture (Gyps africanus CR), Lappet-faced Vulture (Torgos tracheliotos EN) are still in existence.

Marine environment: The marine part of southern Somalia harbours two small estuaries, some mangroves, long stretches of unspoiled beaches and the northern-most coral reefs of East Africa. The biodiversity of these marine environments has been little studied. It is known to support mammal species, the Dugong (Dugong dugon) as well as five marine reptile species, namely the Green Turtle (Chelonia mydas), the Hawksbill Turtle (Eretmochelys imbricata), the Loggerhead Turtle (Caretta caretta (VU)), the Olive-Ridley Turtle (Lepidochelys olivacea (VU)) and the Leather-Backed Turtle (Dermochelys coriacea (VU)). The tranquillity of the beaches makes the area an important breeding ground for these turtles. However, the locals capture them to use their parts in the manufacture of traditional medicine.

Six species of mangrove trees found in the southern coastal area of Somalia include Avicennia marina, Bruguier gymnorrhiza, Ceriops tagal, Rhizophora mucronat, Sonneratia alba and Xylocarpus granatum. 


\section{CONSTRAINTS AND OPPORTUNITIES}

There are various constraints which have impeded the establishment of a protected area in this region of Somalia. It is important to note that the situation in Somalia is changing and will continue to change. This is expected to have a positive impact on the protection of biodiversity and development of protected areas.

\section{Constraints}

Security and access

Insecurity is a problem in Somalia in general and the proposed protected area in Laga Badana in particular. The militia group, Al-Shabaab, use the area as a passage and safe haven. During the formulation of the IGAD-BMP project (2010-2013) there was optimism that this militia group would be defeated and security re-established. Assurances were made by security agencies such as the Somali Federal Army and AMISOM that the group would be eradicated in 2014. However, the reality is that today Al Shabaab remains active, and are a threat to security in the area.

Security is a prerequisite for the establishment of a protected area or any other conservation effort, and it needs to be established before implementing any activity. In this respect, it is promising that the administration of Jubaland were confident that the regional army with the help of the national army and AMISOM are capable of defeating the terrorist group.

\section{Road infrastructure}

While security is the main factor which limits access into the area, there is also lack of infrastructure such as roads and other means of transport. The main sector which will be developed by the program is the tourist sector and this will not be possible without infrastructure such as roads and airports.

Legislation

Legislation and institutions are weak in all sectors, including environmental management and biodiversity conservation. Existing legislation for management of protected areas is outdated. However, there have been some progress made in legislative and institutional reform. While Somaliland is at the forefront in the reform 
and development of environmental policy, there has been little progress in Puntland and the Federal Government. There is no active reform of environmental policy in Jubaland where the proposed protected area is located.

The establishment of a protected area assumes the availability of legislation that would regulate the establishment and management of such a protected area. There are provisions for the establishment and management of five categories of protected areas, and a national park is not among them. In addition, there are no legal provisions for community-based conservation areas. This is a significant constraint, because it is difficult to foresee how a national park could be established in the absence of the requisite legal provisions.

The establishment of a protected area further assumes that there will be institutions to manage it. While a succession of agencies has been responsible for implementing the Law on Fauna and Forest Conservation, these have been plagued by a chronic lack of funding, which is an impediment to the establishment and management of protected areas.

Rights of people living in the area and community-based conservation

Right of people in the area: The number of people living along the borders of the Bush Bush Game Reserve and the proposed Laga Badana National Park is much higher now than in the 1960s when the game reserve was established and the 1970s when the national park has been proposed. There are various settlements located inside the proposed national park and the development of a national park would need to consider how to handle this situation. There is also a group of Boni who migrated to neighbouring Kenya who need to be considered in the process. During the stakeholder consultation on 16-17 November 2015, participants agreed that it would be important to recognize the rights of the communities who occupy these areas. Suggestions were made to change the boundary of the game reserve and the proposed national park to accommodate agricultural and residential land use of the communities living in the area. Another possibility would be to develop opportunities for community-based wildlife conservation and protected area management. 


\section{Participatory biodiversity conservation and protected area management}

Participatory biodiversity conservation calls for the inclusion of local communities living adjacent to a biodiversity resource in its management and conservation. This will bring together all the stakeholders dealing with biodiversity and allow them to work together towards successful biodiversity conservation while taking into consideration the interests of all parties.

This approach ensures that the roles of each stakeholder are defined and their contribution to biodiversity clearly outlined. One of the positive pledges which came out from the workshop was that the representatives of the SFG have agreed to coordinate with the Jubaland administration to take the environmental issue forward and ensure restoration of flora and fauna to foster the economic and social wellbeing of populations living in the area as well as promote the tourism sector, which used to support the country's economy.

\section{Capacity building}

Somalia lacks wildlife/vegetation conservation experts and skilled personnel, to manage and oversee the establishment of the protected area. Hence, capacity building through short courses or establishment of vocational schools where biodiversity conservation is taught should be organized at national and regional level by the Somali Federal Government with the support of regional and international communities.

\section{Opportunities}

\section{Economic development}

Once Laga Badana protected area is established, opportunities to support the economic development of the communities in the area will emerge. The tourist sector will be revamped once hotels, restaurants, airports and other businesses have been put up. This means increased job opportunities and hence increased income for the households in the area. Tax and revenues from various investments in the area will improve the overall economy of the country. Once the tourism sector is revived, traffic at Kismayo Port will increase, and this will be beneficial to the communities in the region. 


\section{Restoration of land and vegetation}

The damaged land, vegetation and wildlife need to be restored by creating the right environmental conditions. To achieve this, certain steps need to be taken. They include: enforcement of environmental legislations and regulations by the Somali Government to minimize the exploitation and clearing of the native vegetation for charcoal production and its export through Kismayo Port. Alternative livelihood programmes could be developed for charcoal producers and traders to help in the conservation of vegetation.

\section{Restoration biodiversity and establishing connectivity across the border}

The cross-border exchanges between the communities will enhance restoration of security and exchange of knowledge between the two countries. This will ease the movement of wildlife across the borders to enrich the reduced biodiversity of the Laga Badana Area.

Community-based conservation and protected area management.

Community-based conservation: In the past, conservation movements disregarded the interests of local inhabitants (Brockington 2002). The object of community-based conservation incorporates improved standards of living for the locals while promoting conservation areas through the creation of national parks and reserves. (Gezon 1997). This model of conservation would be appropriate in places where different communities live together hence theneed for social cohesion, grazing model to address grazing activities and rangeland management. While there have been some notable successes, community-based conservation has often faced challenges of inadequate resources, insufficient support from the federal government, insecurity and poor management.

In Somalia the community-based conservation model presents an opportunity in that, if biodiversity is conserved, browsers will have enough to feed on and will multiply. The predators will then have enough prey to hunt and feed, livestock and crops will be safe from wildlife destruction and humans will have enough to eat. This will ensure that there is no conflict between humans and wildlife. 
Aside from conflict resolution, the community-based conservation model will present an opportunity to promote social cohesion where people from different ethnic communities and clans could interact and exchange ideas on issues affecting them.

Other opportunities

The security situation in the country is gradually improving, thus creating room for the development of institutions, laws and building capacity for the protected areas. The availability of funding sources predominantly from regional and international NGOs, including IGAD, and the presence of AMISOM in the southern part of the country is promoting security. 


\section{VISION FOR ESTABLISHMENT OF A NATIONAL PARK}

\section{The vision}

During the workshop of November 2015 there was consensus on the establishment of one or more protected areas to preserve the diversity, abundance and ecological integrity of all physical, ecological and biological resources for use by the present and future generations. First, to establish an ensemble of conservation areas composed of a national park and community managed conservation areas in the Laga Badana area that would combine conserving the biodiversity and wider environment of the area would be established.

Second, all relevant stakeholders would be engaged, including the local inhabitants of the area, the Federal Government, Jubaland administration and others in the establishment and management of the national park. Third, modalities for communitybased activities would be developed to allow the locals retain rights to the land that they use or previously used and to benefit from the biodiversity and other opportunities offered by these areas. Fourth, existing legislation (i.e. the law on Fauna and Forest Conservation) would be revised. This would include clarification of the mandates of Federal Member States and other stakeholders in the development and management of various categories of conservation areas. Fifth, there is need to develop a road map for establishment of protected areas in the Laga Badana area that recognizes the impediments imposed by lack of security in the area.

\section{Road map for establishment of a protected area}

Security: This is a prerequisite for implementation of the road map. However, here are some activities that can begin right away. These include those involving revision of policies and institutional reforms.

Review and revise existing policy: The revised policy should provide a clear vision on the institutions responsible for the implementation of the legislation. It should also be clear on the mandates and roles of the various levels of government and nongovernmental stakeholders in biodiversity conservation and protected area management. It is recommended that legal frameworks that provide significant roles and mandates to local communities and stakeholders in the creation and management 
of protected areas be developed. Finally, the team should consider borrowing from the best practices that are already being implemented in neighboring countries.

Vision for cross-border conservation area: Develop a vision and plan for cross-border biodiversity conservation that would connect species populations and conservation areas on the Somali side of the border with those on the Kenyan side of the border.

Engage with stakeholders: Identify and engage with all stakeholders who have an interest in biodiversity conservation and the development of conservation areas. This would include raising their awareness.

Review the area's biodiversity: The biodiversity assessment by Gedow (2016) revealed that the data is incomplete and mostly outdated. An assessment of the areas will need to be undertaken. It should include a review of the degradation status of the various habitats and its effects on biodiversity and the opportunities for recovery of degraded habitats.

Plan for protected areas in the Laga Badana area: The next step would be to develop a plan for establishment of one or more protected areas, building on the stakeholder aspirations and the biodiversity assessments.

Establish protected areas in the Laga Badana area: This would include a wide circle of stakeholders to ensure multiple goals including biodiversity conservation, fostering the economic development and improving the living standards of the communities in the area are achieved.

Community awareness raising: To raise awareness and build the capacity of communities. Some activities would include:

1. Re-adjust the boundaries of the protected area to ensure that settlements located at the boundaries of the protected area fall outside the conservation area;

2. Provide Jubaland State and its administration with clear roles in the establishment, management and implementation of the protected area; 
3. The Somali Federal Government and Jubaland State will work together to clarify their respective roles in the establishment and implementation of the protected area and the engagement of other stakeholders. The two would:

- Ensure access of stakeholders into the area

- Provide practical solutions for the adjustment of current boundaries to accommodate settlements in the area

- Prepare funding proposals

- Invite private sector actors to participate in the program

- Be involved in running and managing the protected area based on international standards, while taking into consideration the cultural and political norms of the country. 


\section{REFERENCES}

Abel NOJ, Killeh ME. 1976. Seasonal distribution of wildlife and livestock in relation to development and human resettlement in the southern trans-Juba area of Somalia. Badade District. Field Document NO 4. UNDP/FAO. Strengthening of Forestry and Wildlife Management Project. Mogadishu, DR Somalia.

Abel NOJ. 1976. Management plan for proposed national park. Badade District. UNDP/FAO. Strengthening of Forestry and Wildlife Management Project. Mogadishu, DR Somalia.

African Development Bank. 2013. Country Brief 2013-2015: Somalia. Oreb Department. Bradbury M. 1997. Somaliland. CIIR. Country Report 1997. London Catholic Institute for International Relations.

Brockington D. 2002. Fortress conservation: The preservation of the Mkomazi Game Reserve, Tanzania. International African Institute, Oxford (ISBN 0-253-34079-9)

Burman J, Bowden A, Gole A. 2014. Land tenure in Somalia. A potential foundation for security and prosperity. A Shuraako Review Paper, Shuraako, Mogadishu, 26p, online.

CRD. 2004. Socio-economic assessment of South-Central Somalia, Draft 1. Mogadishu, Somalia.

Davis D, Heywood V, Hamilton A (eds) 1994. Centres of plant diversity. Vol 1: Europe, Africa, Southwest Asia and the Middle East. World Wide Fund for Nature and IUCN, Oxford, UK.

Friis I. 1992. Forests and forest trees of northeast tropical Africa. HMSO, Kew Bulletin Additional Series XV.

FSAU. 2003. Food Security Outlook, FSAU. Nairobi.

Gezon L. 1997. Institutional structure and the effectiveness of integrated conservation and development projects: Case study from Madagascar, Human Organization 56(4), pp. 462-470.

GoK. 2002. Water Act. Government of Kenya, Nairobi.

GoK. 2005. Forest Act. Government of Kenya, Nairobi.

GoK. 2013. Wildlife Conservation and Management Act. Government of Kenya, Nairobi. 
GoS. 1969. Law on Fauna (Hunting) and Forest Conservation (No 15 of 1969). Somalia. FAOLEX Legislative data base of FAO legal office. 25 January 1969.

GoS. 1989. The Mogadishu Manifesto on the Status and Conservation of Somali Wildlife. Government of Somalia, Mogadishu, November 1989.

IUCN. 1991. Somalia. In: Protected areas of the world: Afrotropical, pp. 255-264. Online. IUCN. 2000. Financing protected areas: Guidelines for protected area managers. IUCN, Gland, Switzerland and Cambridge, UK. Online.

IUCN. 2015. Red list of threatened species, IUCN, 2015-4.

Kingdon J. 1997. The Kingdon Field Guide to African Mammals. Academic Press, London.

MoFMR. 2014. Fifth National Report on the Implementation of the Convention on Biological Diversity of Somalia. Ministry of Fisheries and Marine Resources, Mogadishu, Somalia Online

Panayotou T. 1994. Economic instruments for environmental management and sustainable development. Environment and Economics Unit, UNEP, New York.

Pratt DJ, Greenway PJ, Gwynne MD. 1966. A classification of East African Rangelands. J. Appl. Ecol. 3: 368-382.

Roth M. 1993. Somalia land policies and tenure impacts: The case of the Lower Shebelle. In: Basset TJ, Crummey DE (eds) Land in African agrarian systems. University of Wisconsin Press.

Samatar SS. 1993. The society and its environment. In: Metz HC (ed) Somalia: A country study. 4th edition, Library of Congress, Federal Research Division, Washington DC.

Scholte P. 2000. Towards consensual park management planning in Africa. Opinion in Oryx 34: 87-9.

UNEP. 1987. Coastal and marine environmental problems of Somalia. UNEP Regional Seas Reports and Studies, 84. UNEP, Nairobi, Kenya, Online

Millennium Ecosystem Assessment. 2005. Ecosystems and Human Well-being: Synthesis. Island Press, Washington, DC.

http://www.millenniumassessment.org/documents/document.356.aspx.pdf 
World Bank. 2010. Remittances and economic development in Somalia. An overview. Social Development Papers, No. 38

siteresources. worldbank.org/INTCPR/Resources/WP38_web.pdf 


\section{ANNEXES}

Table A1: Evaluation of Fauna in Laga Badana protected area

\begin{tabular}{|c|c|c|c|c|}
\hline $\begin{array}{l}\text { Common } \\
\text { Name }\end{array}$ & Scientific name & 1970s & 2015 & Ecological Significance \\
\hline Elephant & $\begin{array}{l}\text { Loxodonta } \\
\text { africana }\end{array}$ & + & - & $\begin{array}{l}\text { They design the landscape by opening up woodlands as they feed and } \\
\text { roam creating clearings which allow new plants to grow and naturally } \\
\text { regenerate the forest. } \\
\text { Local people also depend on the natural resources within elephant } \\
\text { habitats for food, fuel and income. Elephants are a popular sight for } \\
\text { tourists/ ecotourism can be a source of income, both domestic and } \\
\text { foreign. } \\
\text { Seed dispersal, especially for large seeds that are not spread by smaller } \\
\text { animals through their dung and shaking off seeds as they traverse and } \\
\text { eat. } \\
\text { The dung as food source for other species as it is a treasure cove of } \\
\text { nutrients. Examples include ground hornbills, banded mongooses, velvet } \\
\text { monkeys, baboons and many insect species. The dung beetles, roll balls } \\
\text { of dung and bury them to store as a food supply for their larvae. Honey } \\
\text { badgers with a rich food source as they will then dig up the dung beetle } \\
\text { balls and feed off the plump grubs inside. } \\
\text { Elephants also provide an opportunity for other animals to feed on rich } \\
\text { fruits that are out of reach. } \\
\text { Seed dispersal-some Acacia species only germinate after the seeds pass } \\
\text { through a giraffe's digestive system. }\end{array}$ \\
\hline Giraffe & $\begin{array}{l}\text { Giraffa } \\
\text { camelopardalis }\end{array}$ & + & - & $\begin{array}{l}\text { They provide food, especially for oxpecker birds that eat Ticks. They perch } \\
\text { on the necks and shoulders of giraffes. } \\
\text { Provide watch for prey animals of different species since their tall necks } \\
\text { and excellent vision allow them to see long distances, spot predators such } \\
\text { as lions and hyenas from far away as the predators creep through the tall } \\
\text { grasses of the plains. } \\
\text { Food for predators; baby giraffes fill an important niche as prey. } \\
\text { Controlling the make-up of the park's grasslands they selectively browse } \\
\text { on certain grass species, which leaves room for others that otherwise } \\
\text { could not compete to move in and promotes a diverse mosaic of edible } \\
\text { plants. }\end{array}$ \\
\hline Rhinoceros & Rhinocerotidae & + & & $\begin{array}{l}\text { Rhinos are a popular sight for tourists/ecotourism can be a source of } \\
\text { income. Influence growth and composition of plant species. } \\
\text { Important prey species for large predators. } \\
\text { Meat for human. }\end{array}$ \\
\hline Hirola & Beatragushunteri & + & + & $\begin{array}{l}\text { Influence growth and composition of plant species. } \\
\text { Important prey species for large predators. }\end{array}$ \\
\hline
\end{tabular}




\begin{tabular}{|c|c|c|c|c|}
\hline & & & & Meat for humans. \\
\hline Hippo & $\begin{array}{l}\text { Hippopotamus } \\
\text { amphibius }\end{array}$ & + & + & $\begin{array}{l}\text { Formation of hippo paths from water to land clears avenues through } \\
\text { which water can flow during wet seasons. Flooding of these paths creates } \\
\text { most of the lagoons and side pools that small fish retreat to during } \\
\text { drought. } \\
\text { Their thick hide is used in making shields and elastic whips. Canine tusks } \\
\text { contain ivory, and is illegally sold on the black market. } \\
\text { They help control baboon populations. Disperse seeds that stick to their } \\
\text { fur. }\end{array}$ \\
\hline Leopard & Pantherapardus & + & + & $\begin{array}{l}\text { Their fur is worn as a symbol of honor and courage. } \\
\text { Medicine men and women sometimes use leopard skins as a remedy for } \\
\text { bad omens. } \\
\text { Captured for pet trade and are targeted by trophy hunters as well }\end{array}$ \\
\hline Hyena & Crocutacrocuta & + & + & $\begin{array}{l}\text { The striped hyena has some benefit in that it consumes unwanted human } \\
\text { refuse. } \\
\text { Help regulate populations of black-backed jackals through predation. } \\
\text { They alter predation frequencies of cheetahs and leopards by stalking } \\
\text { them during hunts and then driving them off of their kills. } \\
\text { Brown hyenas also disperse the seeds of tsama melons, hookeri melons } \\
\text { and gemsbok melons at defecation sites. }\end{array}$ \\
\hline
\end{tabular}


Table A2: Evaluation of flora in the proposed protected area

\begin{tabular}{|c|c|c|}
\hline PROVENANCE & SPECIES & USES \\
\hline \multirow[t]{3}{*}{$\begin{array}{l}\text { Bush land } \\
\text { Lag Dera plain, between Lag Garebey } \\
\text { and Coastal Dune Region (Pratt et al. } \\
\text { 1966), Dudumali Plain, on the coastal } \\
\text { dune and hills }\end{array}$} & $\begin{array}{l}\text { 1. Acacia tortilis } \\
\text { (Umbrella thorn) }\end{array}$ & $\begin{array}{l}\text {-Leaves of young tree browsed by goats, sheep camels and wild animals (elephants). } \\
\text {-Pods-Eaten by all livestock and are often the main source of food. } \\
\text {-Timber, poles, posts, charcoal, fuel, Tannin (bark and root), ----Medicinal uses (vermifuge, skin, oedema, asthma, and allergies) Shade } \\
\text { tree, Fencing (poles and branches) Ropes(bark), Gum Arabic }\end{array}$ \\
\hline & Chloris (windmill grass) & Pasture, fodder, hay, ornamental, thatching \\
\hline & $\begin{array}{l}\text { Dactyloctenium sp. } \\
\text { (Crowfoot grass) }\end{array}$ & $\begin{array}{l}\text {-Seeds used to make chapaties or haluwa, a famine food in Africa, astringent, anthelmintic, tonic. Decoction for dysentery and acute } \\
\text { hemoptysis, seed as pain reliever. } \\
\text {-Diuretic, anti-inflammatory, wounds and ulcers. } \\
\text { Ecological; soil erosion-stabilizes sandy soils. }\end{array}$ \\
\hline \multirow[t]{4}{*}{ Woodland plus bush land } & Terminalia species & $\begin{array}{l}\text {-Wood, shade, ornamental, provide habitat for ants and in turn the ants protect the tree. } \\
\text { Tannins, Dysentery treatment, rheumatic joints }\end{array}$ \\
\hline & Delonyx species & $\begin{array}{l}\text {-Ornamental tree in streets and parks. } \\
\text { It is umbrella-shaped crown as shade tree. The wood is durable and resistant to water, fence posts. } \\
\text {-Seeds of } D \text {. regia are sometimes used as beads, gum from the dried seeds as a binder in the manufacture of tablets, e.g., paracetamol. }\end{array}$ \\
\hline & $\begin{array}{l}\text { Adansonia digitata } \\
\text { (baobab) }\end{array}$ & $\begin{array}{l}\text {-Leaves as vegetables, fodder for animals, medicinal for Circulatory System Disorders Roots (incl. Rhizomes etc.) as food, bark for fibre, } \\
\text { tannins, } \\
\text { Religious, ritual. }\end{array}$ \\
\hline & Combretummolle & $\begin{array}{l}\text { Fuel wood, soil improver, root and rhizomes treat stomach pain, Wood used as firewood and charcoal. Leaves browsed by cattle and } \\
\text { used as green manure. }\end{array}$ \\
\hline Wooded and Bushed Grassland & $\begin{array}{l}\text { Sporobolus - Africana, } \\
\text { indicus. }\end{array}$ & $\begin{array}{l}\text {-Stems and leaves (dry) used in popotilo art as leave mosaic, fibre, } \\
\text {-Seed as food for birds, small mammals. }\end{array}$ \\
\hline
\end{tabular}




\begin{tabular}{|c|c|c|}
\hline & & -The plant is used in enriching blood, reduce swelling and correct gonorrhea. It is also an antifertility drug \\
\hline & Terminallia species & $\begin{array}{l}\text { Wood, shade, ornamental, provide habitat for ants and in turn the ants protect the tree. } \\
\text { Tannins, Dysentery treatment, rheumatic joints }\end{array}$ \\
\hline Riparian Forest & $\begin{array}{l}\text { Diospyros mespiliformis } \\
\text { Kolati (Somali) }\end{array}$ & $\begin{array}{l}\text {-Hard wood for house construction, flooring, joinery and furniture, ship and vehicle body, instruments, tool handle, dugout canoes } \\
\text { (from boles), } \\
\text {-Fruit is edible (raw or dried), fruit juice, and alcoholic drinks, ground to make a porridge additive, pulp for glazing/varnish pottery. } \\
\text {-Edible seeds having a nut like flavor. } \\
\text {-Leaves as vegetables, browsed by livestock. } \\
\text {-Bark produces gum for mending pottery, } \\
\text {-There are reports that the roots treat jaundice, anthelmintic, ease child birth, and treat malaria, pneumonia and syphilis. Bark for } \\
\text { coughs, tuberculosis, leprosy, syphilis, wounds, ulcers, bruises, in veterinary medicine as vermifuge. Leaves can be used to treat fever, } \\
\text { diarrhoea, trypanosomiasis, whooping cough, hiccough, poisoning. Fruit for fungal shin infections, powder for ulcers, seed } \\
\text { administered against headaches. Twigs chewed for cleaning teeth. }\end{array}$ \\
\hline & Garcinia species & \\
\hline
\end{tabular}

1 - Conservation International. Coastal Forests of Eastern Africa. http://www.cepf.net/resources/hotspots/africa/Pages/Coastal-Forests-of-Eastern-Africa.aspx 


\section{Working Paper series}

213. Vulnerability of smallholder farmers and their preferences on farming practices in Buol District, Indonesia http://dx.doi.org/10.5716/WP15724.PDF

214. Dynamics of land use/cover change and carbon emission in Buol District, Indonesia http://dx.doi.org/10.5716/WP15725.PDF

215. Gender perspective in smallholder farming practices in Lantapan, Philippines http://dx.doi.org/10.5716/WP15726.PDF

216. Vulnerability of smallholder farmers in Lantapan, Bukidnon http://dx.doi.org/10.5716/WP15727.PDF

217. Vulnerability and adaptive capacity of smallholder farmers in Ho Ho Sub-watershed, Ha Tinh Province, Vietnam http://dx.doi.org/10.5716/WP15728.PDF

218. Local knowledge on the role of trees to enhance livelihoods and ecosystem services in northern central Vietnam http://dx.doi.org/10.5716/WP15729.PDF

219. Land-use/cover change in Ho Ho Sub-watershed, Ha Tinh Province, Vietnam http://dx.doi.org/10.5716/WP15730.PDF

220. Agroforestry and forestry in Sulawesi series: evaluation of the agroforestry farmer field schools on agroforestry management in South and Southeast Sulawesi, Indonesia http://dx.doi.org/10.5716/WP16002.PDF

221. Farmer-to-farmer extension of livestock feed technologies in Rwanda: A survey of volunteer farmer trainers and organizations http://dx.doi.org/10.5716/WP16005.PDF

222. Projected climate change impact on hydrology, bioclimatic conditions, and terrestrial ecosystems in the Asian highlands http://dx.doi.org/10.5716/WP16006.PDF

223. Adoption of agroforestry and its impact on household food security among farmers in Malawi http://dx.doi.org/10.5716/WP16013.PDF

224. Agroforestry and forestry in Sulawesi series: Information channels for disseminating innovative agroforestry practices to villages in Southern Sulawesi, Indonesia http://dx.doi.org/10.5716/WP16034.PDF

225. Agroforestry and forestry in Sulawesi series: Unravelling rural migration networks. Land-tenure arrangements among Bugis migrant communities in Southeast Sulawesi http://dx.doi.org/10.5716/WP16035.PDF

226. Agroforestry and forestry in Sulawesi series: Women's participation in agroforestry: more benefit or burden? A gendered analysis of Gorontalo Province http://dx.doi.org/10.5716/WP16036.PDF

227. Kajian Kelayakan dan Pengembangan Desain Teknis Rehabilitasi Pesisir di Sulawesi Tengah http://dx.doi.org/10.5716/WP16037.PDF

228. Selection of son tra clones in North West Vietnam http://dx.doi.org/10.5716/WP16038.PDF

229. Growth and fruit yield of seedlings, cuttings and grafts from selected son tra trees in Northwest Vietnam http://dx.doi.org/10.5716/WP16046.PDF

230. Gender-Focused Analysis of Poverty and Vulnerability in Yunnan, China http://dx.doi.org/10.5716/WP16071.PDF

231. Seri Agroforestri dan Kehutanan di Sulawesi: Kebutuhan Penyuluhan Agroforestri untuk Rehabilitasi Lahan di Sumba Timur, Nusa Tenggara Timur, Indonesia http://dx.doi.org/10.5716/WP16077.PDF

232. Agroforestry and Forestry in Sulawesi series: Agroforestry extension needs for land rehabilitation in East Sumba, East Nusa Tenggara, Indonesia. http://dx.doi.org/10.5716/WP16078.PDF

233. Central hypotheses for the third agroforestry paradigm within a common definition. http://dx.doi.org/10.5716/WP16079.PDF

234. Assessing smallholder farmers' interest in shade coffee trees: the farming systems of smallholder coffee producers in Gisenyi Area, Rwanda http://dx.doi.org/10.5716/WP16104.PDF

235. Review of agricultural market information systems in sub-Saharan Africa. DOI: http://dx.doi.org/10.5716/WP16110.PDF 
The World Agroforestry Centre is an autonomous, non-profit research organization whose vision is a rural transformation in the developing world as smallholder households increase their use of trees in agricultural landscapes to improve food security, nutrition, income, health, shelter, social cohesion, energy resources and environmental sustainability. The Centre generates science-based knowledge about the diverse roles that trees play in agricultural landscapes, and uses its research to advance policies and practices, and their implementation that benefit the poor and the environment. It aims to ensure that all this is achieved by enhancing the quality of its science work, increasing operational efficiency, building and maintaining strong partnerships, accelerating the use and impact of its research, and promoting greater cohesion, interdependence and alignment within the organization.

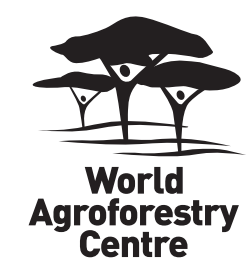

United Nations Avenue, Gigiri • PO Box 30677 • Nairobi, $00100 \cdot$ Kenya Telephone: +254207224000 or via USA +1 6508336645 Fax: +254207224001 or via USA +1 6508336646 Email: worldagroforestry@cgiar.org •www.worldagroforestry.org 